\title{
Selecting and optimizing a reliable DNA extraction method for isolating viral DNA in okra (Abelmoschus esculentus)
}

\author{
T C Jeyaseelan ${ }^{1,4^{*}}$, E C Jeyaseelan ${ }^{1}$, D M De Costa ${ }^{2,4}$, M W Shaw ${ }^{3}$ \\ ${ }^{1}$ Department of Botany, Faculty of Science, University of Jaffna, Jaffna, JA 40000, Sri Lanka. \\ ${ }^{2}$ Department of Agricultural Biology, Faculty of Agriculture, University of Peradeniya, Peradeniya, KY 20400, Sri Lanka. \\ ${ }^{3}$ School of Agriculture, Policy and Development, University of Reading, Reading, RG6 6BZ, United Kingdom. \\ ${ }^{4}$ Plant Protection Board of Study, Postgraduate Institute of Agriculture, University of Peradeniya, Peradeniya, KY 20400, Sri Lanka.
}

*Email: siva.tharmi3@gmail.com

\begin{abstract}
Detection and identification of viruses in okra plant is important to manage viral diseases. Good quality of DNA is essential for the PCR based detection and subsequent genomic sequencing. However, the DNA extraction has been greatly affected by mucilaginous substances present in okra plant parts. Objective of this study is to find out an extraction method that can eliminate mucilaginous materials and yield good quality DNA. Five different protocols were tested with okra leaf samples having okra yellow vein mosaic disease (OYVMD) symptoms. Quantity and purity of extracted DNA was tested using Nanodrop spectrophotometer. Precise quantity comparison was done by measuring total plant DNA in relation to the copy number of ACT2 gene using quantitative polymerase chain reaction (qPCR). The extracted DNA samples were used as template for detection of Bhendi yellow vein mosaic virus and Bhendi yellow vein mosaic betasatellite using specific primers. A modified protocol (modified method 1), introduced in this study, produced better yield and quality of DNA compared to other tested protocols. The method yielded $32 \mu \mathrm{g}$ DNA for $100 \mathrm{mg}$ leaf powder and the ratios A260/A280 and A260/A230 were 1.8 and 2.1, respectively. The qPCR quantification further confirmed higher quantity of DNA yield in this modified protocol. End point PCR with virus specific primers yielded very bright bands for Bhendi yellow vein mosaic virus and Bhendi yellow vein mosaic betasatellite. In conclusion, the modified method 1 can be used to extract good quality and quantity of DNA from okra.
\end{abstract}

Keywords - Okra, DNA extraction, plant viruses

\section{INTRODUCTION}

Detection and identification of plant viruses is the basis to manage plant diseases and to predict the crop loss by the infection. There are various approaches to detect and identify the viruses associated with diseased plants. Nucleic acid-based diagnostic techniques such as hybridization, amplification of targeted viral genome or genomic component(s) by the polymerase chain reaction (PCR) and DNA sequencing have overwhelmingly replaced the use of microscopical and serological techniques (Jose and Usha, 2000; Sharma et al., 2005; Khan et al., 2007; Kushwaha et al., 2010). Nucleic acid based diagnostic techniques are more reliable, specific and reproducible. Better quality and enough quantity of virus genomic DNA or RNA are pre-requisite since the genomic components of the viruses are mixed with cellular constituents of infected plant tissues (Swanson et al., 1992).

DNA extraction from some plant tissues remains difficult due to the contamination of secondary metabolites (Cavallari et al., 2014). Plants such as Okra (Abelmoschus esculentus), Mesta (Hibiscus cannabinus), Jute (Corchorus sp.) and Sida (Sida sp.) possess large amounts of viscous mucilage, which often have secondary metabolites, such as polysaccharides, phenolic compounds, tannins, and alkaloids (Höfer et al., 1997; Jose and Usha 2003; Ghosh et al., 2008; Roy et al., 2009). The viscous mucilage co-precipitates with DNA during total DNA extraction and reduces the quality of the extracted DNA. In addition, attempt to remove the mucilaginous substances always associated with reduction in total DNA quantity (Bayer et al., 1999). The mucilage contamination makes the DNA unmanageable during pipetting and interferes with further downstream applications, such as PCR or other enzymatic reactions (Fang et al., 1992). The concentration and viscosity of mucilage varies from one plant species to other or among different cultivars of one species is due to the chemical complexity and variation in the physiological properties (Muralikrishna et al., 1989; Kawamura et al., 2000; Axel Diederichsen et al., 2006)

Finding out a rapid, simple and reliable DNA extraction protocol is most vital in PCR based diagnosis of virus diseases in plants. Cetyl trimethyl ammonium bromide (CTAB) method is one of the most common methods for DNA extraction from plant samples (Doyle and Doyle, 1987). However, a CTAB extraction procedure does not guarantee the elimination of some contaminants such as lipids, phenolic compounds, and viscous polysaccharides (Pedersen et al., 2006). There are several modified versions of CTAB extraction protocols available to extract DNA from virus infected plant tissues (Deng et al., 1994; Mansoor et al., 1999; Rothenstein et al., 2005; Briddon and Markham, 1994).

Jose and Usha (2000) described a protocol for the extraction of geminiviral DNA from infected okra. This protocol is a combination of a modified CTAB method of Dellaporta et al. (1983) and a citrate buffer extraction with alkali-lysis. However, the method takes too long to get the extracted DNA. 
Ghosh et al. (2009) reported that the DNA extracted by standard CTAB method (Doyle and Doyle, 1987) did not respond to PCR or exhibit inconsistent amplification of virus DNA due to the contamination of mucilaginous substances. Even though the isolated DNA was further purified via DNeasy mini spin column (QIAGEN, GmBH, Hilden, Germany) the PCR amplification was not successful. Therefore, Ghosh et al. (2009) developed a modified CTAB protocol to extract DNA from highly mucilaginous plant samples. The newly developed method gave enough quantity of DNA to Jute plant. However, this method has few drawbacks, such as utilizing large volume of reagents, time consuming and deals with toxic phenol.

The present study describes an improved, rapid, safe and inexpensive, modified method for DNA isolation which is suitable for further downstream amplification of full or partial genome of begomoviruses and betasatellites. The method described in this study has been standardized with okra plants infected with a begomovirus, Bhendi yellow vein mosaic virus (BYVMV) and Bhendi yellow vein mosaic betasatellite (BYVMB).

\section{Materials AND MethodS}

\section{A. Collection of plant samples}

Young Leaf samples showing yellow vein mosaic symptoms were collected from three months old okra plants (Variety TV-8) growing in research field, Agriculture research station, Thirunelveli, Jaffna, Sri Lanka in May, 2015. Symptomless leaf samples were collected from plants which were grown in insect-proof cages. The leaf samples were dried by keeping inside paper towels.

\section{B. DNA extraction}

DNA extraction was done using above leaf samples. Fine powders of the leaf samples were obtained separately by grinding a whole leaf in liquid nitrogen using pre-chilled sterilized mortar and pestle. The aliquots $(20 \mathrm{mg})$ of the fine powder were taken in $1.5 \mathrm{ml}$ Eppendorf tubes separately. Total DNA was extracted using five different protocols including two modified methods which were introduced in this study (Table 1).

Table 1: DNA extraction protocols used in the study

\begin{tabular}{cll}
\hline No. & \multicolumn{1}{c}{ Protocol } & \multicolumn{1}{c}{ Source } \\
\hline 1 & $\begin{array}{l}\text { Cetyl trimethylammonium } \\
\text { bromide (CTAB) method } \\
\text { An improved method of DNA } \\
\text { isolation for mucilaginous plant }\end{array}$ & Doyle and Doyle (1987) \\
3 & $\begin{array}{l}\text { DNeasy plant mini kit } \\
4\end{array}$ & QIAGEN, Germany \\
5 & Modified method I & Proposed in the current study \\
& & Proposed in the current study
\end{tabular}

The protocols 1-3 were carried out as described by the authors or as in manufacturer's guide line and the protocol 4 and 5 are given below. All the chemicals used in the extraction procedures were purchased from Sigma-Aldrich, USA. All the extraction protocols were tested twice.

\section{Protocol 4: Modified method I}

This method was developed by modifying the method described by Ghosh et al. (2009). An aliquot of $5 \mathrm{ml}$ of extraction buffer $(100 \mathrm{mM}$ Tris- $\mathrm{HCl}, 10 \mathrm{mM}$ EDTA, $1.4 \mathrm{M}$ $\mathrm{NaCl}, \quad 2 \% \quad \mathrm{CTAB}, \quad 0.2 \% \quad \beta$-mercaptoethanol and $1 \%$ Polyvinylpyrrolidone (PVP), $\mathrm{pH}$ 8) was taken in $15 \mathrm{ml}$ falcon tube and pre-warmed at $65{ }^{\circ} \mathrm{C}$. $20 \mathrm{mg}$ of leaf powder was added into the pre-warmed buffer and incubated at $65^{\circ} \mathrm{C}$ for $30 \mathrm{~min}$. During incubation period, the suspension was mixed 4 to 6 times by inverting the tubes gently. For removing the organic contaminants, 0.6 volume of chloroform:isoamylalcohol (24:1) was added into the tube and mixed thoroughly for 1-2 min, to form an emulsion. The samples were centrifuged at $4000 \times g$ for $10 \mathrm{~min}$ at room temperature and the upper aqueous phase was transferred to a fresh tube. Two-thirds of volume of cold iso-propanol was then added and mixed well by inverting the tube gently. The nucleic acid was collected as pellet by centrifuging at $4000 \times g$ for $10 \mathrm{~min}$. The pellet was air-dried and re-suspended in $1 \mathrm{ml}$ of TE buffer. The solution was transferred to a fresh $2 \mathrm{ml}$ micro-centrifuge tube and treated with RNase at $37^{\circ} \mathrm{C}$ for $10 \mathrm{~min}$ in heating block. Then equal volume of chloroform: iso-amylalcohol (24:1) was added and mixed thoroughly to form an emulsion. The samples were centrifuged at $16,500 \times g$ for $5 \mathrm{~min}$ at room temperature and the upper aqueous phase was transferred to a fresh tube. A double volume of absolute ethanol was added into the above aqueous phase and mixed gently by inverting the tube to precipitate the DNA. After centrifugation at $4000 \times g$ for 10 min at $4{ }^{\circ} \mathrm{C}$, the DNA pellet was washed with washing buffer, composed of ethanol (76\%) and ammonium acetate $(10 \mathrm{mM})$. Finally the air-dried DNA pellet was dissolved in $75 \mu \mathrm{l}$ of TE buffer.

\section{Protocol 5: Modified method II}

The second modified method was developed by combining CTAB method and commercial DNA extraction kits. The procedure was similar to protocol 4 up to precipitation of nucleic acid by adding chilled iso-propanol. The resulting pellet was used for further extraction using DNeasy plant minikit using manufacturer's instruction.

\section{Measuring the quality and quantity of extracted total DNA}

To measure the DNA concentration, $1.5 \mu 1$ of extracted DNA of each sample was loaded in Nanodrop spectrophotometer (Nanodrop 2000, Thermo scientific) and the concentration was measured at $260 \mathrm{~nm}$ wave length. The quality of the extracted DNA was measured based on the reading that obtained from A260/A280 nm and A260/A230 nm. 


\section{Quantification of plant DNA in the extracted total DNA using $q P C R$}

The plant DNA in each extracted DNA sample was quantified and compared in relation to amount of plant actin gene. Pair of primers ACT2 F and ACT2 R (Table 2) amplifying a 68-bp genomic fragment of the ACT2 gene (Che et al., 2010) was used in this experiment.

Quantification was done by absolute quantification method. The standard curve was prepared with known concentration of plant DNA which extracted from symptomless leaf samples. $50 \mathrm{ng} / \mu \mathrm{l}$ DNA extracted from leaf of virus free okra were tenfold serially diluted up to the final concentration $0.005 \mathrm{ng} / \mu \mathrm{l}$. For each reaction $20 \mu \mathrm{l}$ reaction mix was prepared by adding $10 \mu \mathrm{L}$ SYBR Green mix (PCR BIOSYSTEM, UK), $1.5 \mu \mathrm{l}$ of plant primer $(5 \mu \mathrm{M})$ ACT2, $1 \mu 1$ template DNA and rest of the volume was adjusted with nuclease free water. Quantity of $A C T 2$ gene in each DNA test sample (extracted using different protocols) was measured in the same reaction plate ( 96 well PCR plate) by adding $1 \mu 1$ of each DNA samples. No template control (NTC) reactions were carried out with nuclease-free water instead of DNA samples. The qPCR reaction was carried out in duplicates under conditions optimized for the primer $\left(95^{\circ} \mathrm{C}\right.$ for $10 \mathrm{~min}$ and 40 cycles of $60{ }^{\circ} \mathrm{C}$ for $1 \mathrm{~min}, 95^{\circ} \mathrm{C}$ for $15 \mathrm{~s}$ ) using a Step One Plus Real Time PCR system (Applied Biosystems, USA). At the end of the reaction a melting curve analysis was performed from 60 to $95^{\circ} \mathrm{C}$, with an increment of $0.5^{\circ} \mathrm{C}$ at $10 \mathrm{~s}$ intervals.

\section{E. Detection of virus DNA in extracted total DNA using end point PCR}

The extracted total DNA was used as template in PCR for amplification of a segment of begomovirus DNA-A and whole genome of betasatellite associated with OYVMD. Primer pair MKBEGF4 and MKBEGR5 (Venkataravanappa et al., 2012) was used to amplify 1.3 kilobase partial DNA-A and the universal primer pair $\beta 01$ and $\beta 02$ (Briddon et al., 2002) were used to amplify the betasatellite DNA (Table 2).

Table 2: List of primers used in end point PCR and qPCR reactions

\begin{tabular}{|c|c|c|}
\hline Primer & Target DNA & Primer sequence (5', to $\left.3^{\prime}\right)$ \\
\hline$\beta 01$ & \multirow{2}{*}{ Beta satellite DNA } & $\begin{array}{l}\text { GGTACCACTACGCTACGCAG } \\
\text { CAGCC }\end{array}$ \\
\hline$\beta 02$ & & $\begin{array}{l}\text { GGTACCTACCCTCCCAGGGG } \\
\text { TACAC }\end{array}$ \\
\hline MKBEGF4 & \multirow{2}{*}{$\begin{array}{l}\text { Segment of DNA-A } \\
\text { of Begomovirus }\end{array}$} & $\begin{array}{l}\text { ATATCTGCAGGGNAARATHT } \\
\text { GGATGGA }\end{array}$ \\
\hline MKBEGR5 & & $\begin{array}{l}\text { TGGACTGCAGACNGGNAAR } \\
\text { ACNATGTGGGC }\end{array}$ \\
\hline $\mathrm{ACT} 2 \mathrm{~F}$ & \multirow{2}{*}{$\begin{array}{l}\text { Segment of actin } \\
\text { gene of plant }\end{array}$} & CTTGCACCAAGCAGCATGAA \\
\hline ACT2 R & & $\begin{array}{l}\text { CCGATCCAGACACTGTACTT } \\
\text { CCTT }\end{array}$ \\
\hline
\end{tabular}

A $20 \mu 1$ of PCR reaction mix was prepared by adding, $10 \mu 1$ of PCR readymade mix (PCR BIOSYSTEM, UK), $1 \mu$ of each primer $(10 \mu \mathrm{M}), 3 \mu \mathrm{l}$ of DNA template $(10 \mathrm{ng} / \mu \mathrm{l})$ and $5 \mu \mathrm{l}$ of nuclease free water. The reactions were carried out in a thermal cycler (Veriti®, Applied Biosystem, USA). For the partial amplification of DNA-A, the cycling conditions were maintained as follows; an initial denaturation at $94{ }^{\circ} \mathrm{C}$ for $3 \mathrm{~min}$, followed by 35 cycles of denaturation at $94{ }^{\circ} \mathrm{C}$ for $1 \mathrm{~min}$, annealing temperature at $60^{\circ} \mathrm{C}$ for $45 \mathrm{~s}$ and extension at $72{ }^{\circ} \mathrm{C}$ for $1 \mathrm{~min}$ with a final extension for $5 \mathrm{~min}$ at $72{ }^{\circ} \mathrm{C}$. Similarly, the full length of betasatellite DNA was amplified with following PCR conditions; with initial denaturation at $94{ }^{\circ} \mathrm{C}$ for 5 min followed by 35 amplification cycles with melting at $94{ }^{\circ} \mathrm{C}$ for $1 \mathrm{~min}$, annealing temperature at $58^{\circ} \mathrm{C}$ for $1 \mathrm{~min}$, extension for $1.5 \mathrm{~min}$ at $72{ }^{\circ} \mathrm{C}$ and final extension at $72{ }^{\circ} \mathrm{C}$ for $5 \mathrm{~min}$. For both reactions, the optimum annealing temperature was determined by carrying out the temperature gradient PCR reaction with temperature ranging from $52{ }^{\circ} \mathrm{C}$ to $62{ }^{\circ} \mathrm{C}$.

The PCR products were mixed with loading dye and run on $1.5 \%$ agarose gel at 90 volts for $30 \mathrm{~min}$. Hyper-ladder I (Bioline, United Kingdom) was used as standard. The gel was stained with ethidium bromide and viewed on a Gel documentation system (UVP ChemiDoc-It TS2 Imager, United Kingdom).

\section{F. Data analysis}

Absolute quantification of plant DNA was determined by running the default settings of the StepOne ${ }^{\mathrm{TM}}$ Real-Time PCR Software Version 2.3 (Life technologies, USA) on the StepOne Plus ${ }^{\mathrm{TM}}$ Real-Time PCR systems (Applied Biosystems USA). The data were subjected to ANOVA in IBM SPSS Statistics for Windows, Version 21.0.

\section{RESUlts}

Five different DNA extraction protocols were tested to find out the protocol which can yield good quality and quantities of DNA extracted from okra leaves affected by OYVMD. The protocol 4 (modified method I), one of the methods that we introduced in this study, yielded higher concentration of DNA with good quality (Table 3); the average concentration of extracted total DNA was $85.8 \mathrm{ng} / \mu 1$ and the ratios A260/A280 and A260/A230 were 1.8 and 2.1 respectively. The total DNA extracted from $100 \mathrm{mg}$ of the sample was $32.1 \mu \mathrm{g}$.

All other extraction methods, except protocol 5 (modified method II), produced a moderate yield; the concentration of the extracted total DNA ranged from $31 \mathrm{ng} / \mu 1$ to $50 \mathrm{ng} / \mu \mathrm{l}$. However, the nano-drop reading for the quality measure of those DNA samples was not in the acceptable range in most of the samples. The protocol 5 (modified method II) yielded comparatively lowest quantity and quality DNA than other methods tested in this study (Table 3). 
Table 3: Nano-drop spectrophotometer reading for the quantity and quality of total DNA extracted from leaf samples of okra

\begin{tabular}{lcccc}
\hline \multicolumn{1}{c}{ Methods } & $\begin{array}{c}\text { Concentration } \\
(\mathbf{n g} / \boldsymbol{\mu l})\end{array}$ & $\begin{array}{c}\text { Total yield } \\
(\boldsymbol{\mu g} / \mathbf{1 0 0} \mathbf{~ m g})^{\mathbf{b}}\end{array}$ & $\begin{array}{c}\text { Ratio } \\
(\mathbf{A 2 6 0 / A 2 8 0})^{\mathbf{c}}\end{array}$ & $\begin{array}{c}\text { Ratio } \\
(\mathbf{A 2 6 0} / \mathbf{A 2 3 0})^{\mathbf{d}}\end{array}$ \\
\hline Protocol 1: CTAB method & $39.2 \pm 2.4 \mathrm{a}$ & $14.7 \pm 1.3$ & $1.6 \pm 0.09$ & $1.6 \pm 0.02$ \\
Protocol 2: An improved method for mucilaginous plant & $49.1 \pm 2.9$ & $18.4 \pm 1.5$ & $1.8 \pm 0.07$ & $1.5 \pm 0.07$ \\
Protocol 3: DNeasy plant mini kit & $31.3 \pm 1.5$ & $11.7 \pm 0.8$ & $1.6 \pm 0.07$ & $2.1 \pm 0.12$ \\
Protocol 4: Modified method I & $85.8 \pm 2.1$ & $32.1 \pm 1.1$ & $1.8 \pm 0.05$ & $2.1 \pm 0.17$ \\
Protocol 5: Modified method II & $16.3 \pm 2.0$ & $6.1 \pm 1.0$ & $1.7 \pm 0.08$ & $2.4 \pm 0.10$ \\
\hline
\end{tabular}

${ }^{a}$ Mean value of three biological replicates with standard deviation from mean

${ }^{\mathrm{b}}$ Amount of DNA yield in $100 \mathrm{mg}$ leaf powder

${ }^{c}$ Acceptable reading is 1.8

${ }^{\mathrm{d}}$ Acceptable range is 2-2.2.

qPCR assay for the quantification of plant DNA in relation to the quantity of actin gene showed results similar to nano-drop quantification in most of the samples (Figure 1). The quantity of the plant DNA in $1 \mu \mathrm{l}$ of total DNA extracted according to the protocol 4 was $15.45 \mathrm{ng}$. It is significantly greater than the quantity of plant DNA in the DNA extracts of rest of the protocols. In protocol 2 and protocol 1 the amount of plant DNA was $8.30 \mathrm{ng}$ and $5.81 \mathrm{ng}$ respectively in $1 \mu \mathrm{l}$ of total DNA samples. The nano-drop reading of DNA quantity for protocol 3 and protocol 5 contradict from qPCR quantification. The quantity of DNA obtained in protocol 3 was twofold higher than obtained in protocol 5. But in qPCR no significant variation was observed. However, in both type of quantifications the amount of DNA in protocol 3 and protocol 5 was comparatively lower than the rest of the protocols.

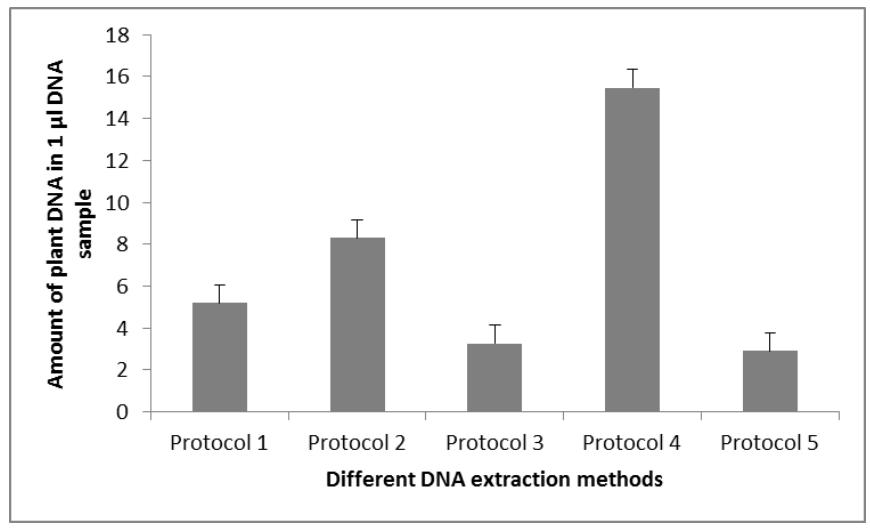

Figure 1. Amount of plant DNA in relation to the amount of actin gene copies in $1 \mu 1$ total DNA extracted by five different methods. Protocol 1CTAB method, Protocol 2- An improved method of DNA isolation for mucilaginous plant, Protocol 3- DNeasy plant mini kit, Protocol 4- Modified method I, Protocol 5- Modified method II. S. E. $=0.87$.

End-point PCR was carried out to detect the beta-satellite DNA and DNA-A of OYVMV in the extracted total DNA samples. Presence of DNA bands with expected size (about 1.3 kilobase pair) in gel image indicates that all the tested extracts contain virus DNA (Figure 2). However, the intensity of the bands was not similar in all tested samples, which show variation in quantity of DNA in the tested samples. The bright band indicates higher copy number of the virus DNA and faint band indicates lower copy number of the virus DNA. Bright bands were observed in DNA samples extracted using protocol 1, protocol 2 and protocol 4 for both beta-satellite and DNA-A of OYVMV and less faint bands in DNA samples extracted using protocol 5 . However, the results obtained for the DNA extracted in protocol 3 was not consistent; a brighter band was noticed for the amplification of DNA-A, but less bright band was for the beta-satellite DNA.

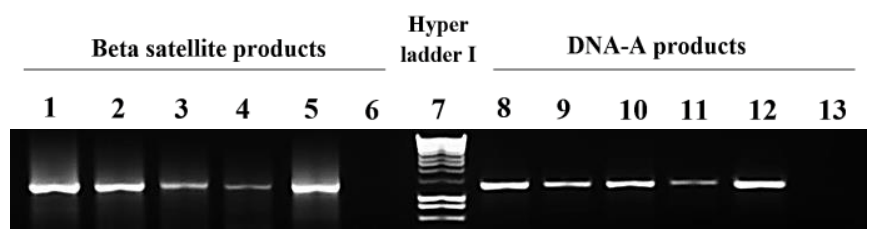

Figure 2. Comparison of different DNA isolation methods based on PCR amplified products of beta-satellite (1-6) and partial DNA-A (8-13). Amplification was detected in all samples with beta-satellite specific primers: (1) modified method I, (2) CTAB method. (3) DNeasy plant mini kit, (4) modified method II, (5) an improved method of DNA isolation for mucilaginous plant. Amplification was detected in all samples with DNA-A specific primers: (8) modified method I, (9) CTAB method. (10) DNeasy plant mini kit, (11) modified method II, (12) an improved method of DNA isolation for mucilaginous plant. No amplification was noticed in non-target control $(6,13)$

\section{DISCUSSION}

Most of the Malvaceae family members, including okra, have mucilaginous substances in their leaves and other plant parts. The mucilaginous substances greatly interfere in DNA extraction from these plant parts. In the present study, five different DNA extraction methods were tested and analysed to find out a best DNA extraction method that can yield higher quality and large quantity of DNA from okra leaves with the major aim to detect virus DNA. A modified DNA extraction method which was developed in this study (Protocol 4 Modified method I) produced better quality and quantity of DNA, in addition, the extracted total DNA had large quantities of virus DNA.

Earlier, Ghosh et al. (2009) developed a modified CTAB method and recommended for the DNA extraction from highly 
mucilaginous plants including okra. However, the protocol has some negative aspects such as using a highly toxic phenol in the extraction, the volume of reagents or buffers are relatively high and it takes too long and hard to re-suspend the DNA pallet in $\mathrm{NaCl}$. In the present study, the modified method 1 is a modified version of the method described by Ghosh et al. (2009). However, the quantity of the DNA extracted in modified method 1 is twofold higher than the quantity of DNA extracted in the method described by Ghosh et al. (2009) (Table 3). The quality of the DNA extracted using the method described by Ghosh et al. (2009) was comparatively lower than the quality of DNA extracted in modified method 1; this might be due to the contamination of some amount of proteins and great amount of carbohydrates and phenolic compounds (Abdel-Latif and Osman., 2017).

Addition of PVP enhances the removal of secondary plant metabolites, especially polyphenolic compounds. The PVP binds with phenolic compounds and helps in their removal (Rezadoost et al., 2016). The superfluous quantities of cellular proteins were managed by twice extended treatment with chloroform-isoamyl alcohol. In addition to the removal of proteins, this treatment also helps to remove different coloring substances such as chlorophyll, pigments, and dyes (Azmat et al., 2012).

Phenol: chloroform extraction was not included in modified method 1 to avoid potential health hazards. Phenol is irritating to the skin, rapidly absorbed through the skin. Special protections are needed to handle this chemical. Therefore, nowadays researchers try to avoid using phenol in DNA extraction protocols.

In the method proposed by Ghosh et al. (2009), the crude nucleic acid pellet was dissolved in $1 \mathrm{M} \mathrm{NaCl}$. It took more than $30 \mathrm{~min}$ to partially re-suspend the pellet, therefore, it is time consuming and tedious when handling several samples at a time. In modified method 1, TE buffer was used to dissolve crude nucleic acid pellet; the pellet dissolved quickly, within 3 to $5 \mathrm{~min}$. This modification did not affect the quantity and quality of the extracted DNA.

Mostly researchers use RNase to remove RNA that coextracted with DNA. Studies have proved that RNase removing substantial quantities of DNA under common experimental conditions (Dona and Houseley, 2014). Therefore, prolonged treatment with RNase may also affect the quality and quantity of the DNA. Therefore, the RNase incubation time was reduced to 10 minutes. Dona and Houseley (2014) has proved that RNase treatment followed by phenol:chloroform purification step, as described in Ghosh et al. (2009), significantly reduced the yield of the DNA extraction.

Even though both CTAB method (Doyle and Doyle, 1987) and DNeasy plant mini kit method produced a moderated quantity of total DNA, the ratio of A260/A230 or A260/280 was greatly low. This could be due to the contamination of carbohydrates and phenolic compounds. In order to reduce these contaminants, in modified method 1 chloroform-isoamyl alcohol extraction was carried out twice.

The detergent CTAB can be used to isolate highly polymerized DNA from plant. It produces the conformational change in the DNA from random coil to compact globule, making DNA precipitation more effective. CTAB and chloroform:isoamyl alcohol mixture separates contaminants into the organic phase and nucleic acid into the aqueous phase (Doyle and Doyle, 1987). But, many plants have very high levels of secondary metabolites, including lipids, phenolic compounds and viscous polysaccharides. These can be removed by doing further processing, commonly with organic solvents, such as phenol or other toxic compounds (Pedersen et al., 2006; Bashalkhanov and Rajora, 2008; Bellstedt et al., 2010). The phenolic compounds are powerful oxidizing agents and bind covalently to extracted DNA making it useless for most of the molecular manipulation. Thus, if they are not removed properly, then they hinder subsequent downstream assays including PCR (Porebski et al., 1997; Angeles et al., 2005).

Using commercial DNA extraction kits is easier, faster and relatively less hazardous than the conventional extraction methods. The extraction using commercially available kits consist of comparatively few steps for the completion of the entire extraction process, but it is expensive. For experiments with large scale DNA extraction and screening, the cost of the kits gives extra burden, especially to the researchers in developing countries. Conversely, conventional methods are cheaper even though they consume too long for extraction steps. The average completing time for the modified method 1 was approximately $2 \frac{1}{2}$ hours, handling 10 samples at the same time. In overall, the results indicated that the DNA extraction using modified method 1 is advantageous over the other conventional methods with respect to the time, yield of the DNA and reproducibility by PCR.

There have been numerous reports of extraction of begomoviral DNA from wide range of plant species rich in mucilage and polysaccharides including okra (Jose and Usha, 2000), Bixa (Echevarria-Machado et al., 2005), Sedum (Barnwell et al., 1998), cotton (Mansoor et al., 1999), forest plants (Scott and Playford, 1996) and legumes (Rouhibakhsh et al., 2008). Besides their specificity towards a particular plant species, most of these protocols are either time consuming or involve some additional reagents such as polyethylene glycol and silica which make these methods expensive and cumbersome.

Based on the findings of this study, the modified method 1 is a highly suitable method for the extraction of DNA from okra, because of higher yield and good quality of the extracted DNA. The DNA extracted in this method is highly useful in 
downstream applications such as PCR based detection, identification and quantification of virus DNA.

\section{ACKNOWLEDGEMENT}

The authors are grateful to Dr. George Gibbings and Dr. Ihsan Ullah for technical assistance in Molecular genetics laboratory, School of Agriculture, Policy and Development, University of Reading, U.K. The works in Sri Lanka was supported by University Grants Commission, Government of Sri Lanka under the project: UGC/DRIC/PG/2015(ii)/JFN/01 is duly acknowledged.

\section{REFERENCES}

Abdel-Latif, A and Osman, G, (2017). Comparison of three genomic DNA extraction methods to obtain high DNA quality from maize. Plant Methods 13:1. DOI 10.1186/s13007 016 0152-4

Angeles, J, Laurena, A and Evelyn Mae T, (2005). Extraction of Genomic DNA From the lipid- ,polysaccharide-, and olyphenol-rich cocont (Cocos nucifera L.). Plant Molecular Biology Reporter 23, 297-298.

Axel Diederichsen, J, Philip, R and Duguid S, (2006). Variation of mucilage in flax seed and its relationship with other seed characters. Crop Science 46, 365- 371.

Azmat, M. A, Khan, I. A, Cheema, H. M. N, Rajwana, I. A, Khan, A. S and Khan, A. A, (2012). Extraction of DNA suitable for PCR applications from mature leaves of Mangifera indica L. Journal of Zhejiang University Science B 13, 239-243.

Barnwell, P, Blanchard, A, Bryant, J, Smirnoff, N and Weir, A, (1998). Isolation of DNA from the highly mucilagenous succulent plant shape Sedum telephium. Plant Molecular Biology Reporter 16, 133.

Bashalkhanov, S and Rajora, O, (2008). Protocol: a highthroughput DNA extraction system suitable for conifers. Plant Methods 4, 20.

Bayer, C, Fay, M and De Bruijn, A, (1999). Support for an expanded family concept of Malvaceae within a recircumscribed order Malvales: a combined analysis of plastid atpB and rbcL DNA sequence. Botanical Journal of the Linnean Society 129, 267-303.

Bellstedt, D, Pirie, M, Visser, J, DeVilliers, M and Gehrke, B, (2010). A rapid and inexpensive method for the direct PCR amplification of DNA from plants. American Journal of Botany 97, 65-68.

Briddon, R. W, Bull, S. E, Mansoor, S, Amin, I and Markham, P. G, (2002). Universal primers for the PCR- mediated amplification of DNA $\beta$. Molecular Biotechnology 20, 315-318.

Briddon, R and Markham, P, (1994). Universal primers for the PCR amplification of dicot-infecting geminiviruses. Molecular Biotechnology 1, 202-205.

Cavallari, M. M, Siqueira, M. V. B. M, Val, T. M and Pavanelli, J. C, (2014). A modified acidic approach for DNA extraction from plant species containing high levels of secondary metabolites. Genetics and Molecular Research 13, 6497-6502.

Che, P, Bussell, J. D, Zhou, W, Estavillo, G. M, Pogson, B. J and Smith, S. M, (2010). Signalling from the endoplasmic reticulum activates brassinosteroid signalling and promotes acclimation to stress in Arabidopsis. Science Signaling 3, ra69.

Dellaporta, S, Wood, J and Hicks, J, (1983). A plant DNA mini-preparation Version II. Plant Molecular Biology Reporter 1, 19-21.

Deng, D, Mcgrath, P. F and Harrison, B. D, (1994). Detection and differentiation of whitefly-transmitted geminiviruses in plants and vector insects by the polymerase chain reaction with degenerate primers. Annals of Applied Biology 125, 327-336.

Dona, F and Houseley, J, (2014) Unexpected DNA loss mediated by the DNA binding activity of ribonuclease A. PLoS ONE 9(12): e115008. doi:10.1371/journal.pone.0115008

Doyle, J and Doyle, J, (1987). A rapid DNA isolation procedure for small quantities of fresh leaf tissue. Phytochemical bulletin 19, 11-15.

Echevarria-Machado, I, Lucila, A, Sanchez, C, HernandezZepeda, C, Rivera-Madrid, R and Moreno-velenzuela O, (2005). A simple and efficient method for isolation of DNA in high mucilaginous plant tissues. Molecular Biotechnology 31, 129-135.

Fang, G, Hammer, S and Grumet, R, (1992). A quick and inexpensive method for removing polysaccharides from plant genomic DNA. Bio Techniques 13, 52-56.

Ghosh, R, Paul, S and Das, S, (2008). Molecular evidence for existence of a New World begomovirus associated with yellow mosaic disease of Corchorus capsularis in India. Australasian Plant Disease Notes 3, 59-62.

Ghosh, R, Paul, S, Ghosh, S. K and Roy A, (2009). An improved method of DNA isolation suitable for PCR-based detection of begomoviruses from jute and other mucilaginous plants. Journal of Virological Methods 159, 34-39. 
Höfer, P, Engel, M, Jeske, H and Frischmuth, T, (1997). Host range limitation of a pseudo recombinant virus produced by two distinct bipartite geminiviruses. Molecular Plant-Microbe Interactions 10, 1019-1022.

Jose, J and Usha, R, (2000). Extraction of Geminiviral DNA from a highly mucilaginous plant (Abelmoschus esculentus). Plant Molecular Biology Reporter 18, 349-355.

Jose, J and Usha, R, (2003). Bhendi Yellow Vein Mosaic Disease in India Is Caused by Association of a DNA betasatellite with a Begomovirus. Virology 317, 310-317.

Kawamura, T, Hisata, Y and Okuda K, (2000). Diversity of alkaloid and mucilage in phellodendron barks from different habitats. Nature Medicine 54, 193-195.

Khan, A.J, Al-saady, N.A, Al-mahruki, M.S, Al-oufi, M and Al-subhi A.M, (2007). Molecular characterization of Begomovirus infecting sweet pepper in Oman. Indian Journal of Biotechnology 6, 45-51.

Kushwaha, N, Singh, A.K, Chattopadhyay, B and Chakraborty, S, (2010). Recent advances in geminivirus detection and future perspectives. The Journal of Plant Protection Sciences 2, 1-18.

Mansoor, S, Bashir, A and Khan, S, (1999). Rapid multiplex PCR for the specific detection of two whitefly-transmitted geminivirus species associated with cotton leaf curl disease in Pakistan. Pakistan Journal of Botany 31, 115-123.

Muralikrishna, G, Bhat, U and Tharanathan, R, (1989). Functional characteristics of the mucilaginous polysaccharides derived from cowpea (Vigna sinensis), black gram (Phaseolus mungo) and linseed (Linum usitatissimum). Starch 39, 107-109.

Pedersen, N, Russel, S, Newton, A and Ansell, S, (2006). A novel molecular protocol for the rapid extraction of DNA from byrophytes and the utility of direct amplification of DNA from a single dwarf male. The Bryologist 109, 257-264.
Porebski, S, Bailey, L and Banum, B, (1997). Modification of a CTAB DNA extraction protocol for plants containing high polysaccharide and polyphenol components. Plant Molecular Biology Reporter 15, 8-15.

Rezadoost, M.H, Kordrostami, M and Kumleh, H.H, (2016). An efficient protocol for isolation of inhibitor-free nucleic acids even from recalcitrant plants. 3 Biotech 6,61 .

Rothenstein, D, Haible, S, Dasgupta, I, Dutt, N, Patil, B and Jeske, H, (2005). Biodiversity and recombination of cassavainfecting begomoviruses from southern India. Archives of Virology 151, 55-69.

Rouhibakhsh, A, Priya, J, Periasamy, M, Haq, Q and Malathi, V, (2008). An improved DNA isolation method and PCR protocol for efficient detection of multicomponents of begomovirus in legumes. Journal of Virological Methods 147, 37-42.

Roy, A, Acharyya, S and Das, S, (2009). Distribution, epidemiology and molecular variability of the begomovirus complexes associated with yellow vein mosaic disease of mesta in India. Virus Research 141, 237-246.

Scott, K and Playford, J, (1996). DNA extraction technique for PCR in rain forest plant species. Bio Techniques 20, 974-978.

Sharma, P, Rishi, N and Malathi V.G, (2005). Molecular cloning of coat protein gene of an Indian cotton leaf curl virus (CLCuV-HS2) isolate and its phylogenetic relationship with others members of geminiviridae. Virus Genes 30, 85-91.

Swanson, M, Varma, A, Muniyappa, V and Harrison, B, (1992). Comparative epitope profiles of the particle proteins of whitefly-transmitted geminiviruses from nine crop legumes in India. Annals of Applied Biology 120, 425-433.

Venkataravanappa, V, Reddy, C.N.L, Jalali, $\mathrm{S}$ and Reddy M. K, (2012). Molecular characterization of distinct bipartite begomovirus infecting bhendi (Abelmoschus esculentus L.) in India. Virus Genes 44, 522-535. 
